\title{
ПЕРСПЕКТИВЫ РАЗВИТИЯ ЭКОЛОГИЧЕСКИ ЧИСТЫХ БИОЛОГИЧЕСКИ АКТИВНЫХ СОЕДИНЕНИЙ НА ОСНОВЕ БЕНЗИМИДОЗОЛОВ И ИХ ПРОИЗВОДНЫХ
}

\author{
Акбарова М.У. ${ }^{1}$, Охунов Д.М. ${ }^{2}$ \\ ${ }^{1}$ Ферганский политехнический институт, Фергана, Узбекистан, \\ ${ }^{2}$ Ферганский филиал Ташкентского университета информационных технологий \\ имени Мухаммада аль-Хорезми, Фергана, Узбекистан
}

В статье приводятся результаты научных исследований по разработке перспективных экологических чистых пестицидов на основе местного сырья.

Ключевые слова: компьютеризация, пестициды, экономический эффект, регуляторы роста, бензимидазол, фунгициды.

Создание новых эффективных биологически активных веществ лекарственных средств, пестицидов - остаётся актуальной задачей. Отсутствие теоретических основ их поиска даёт решение задачи чрезвычайно сложным, длительным и дорогостоящим.

Существенную помощь в поиске могут оказать формализационные подходы к изучению связи между строением и действием химических соединений. Компьютеризация все более широких сфер научной деятельности позволяет внедрить компьютерные методы в области химии биологических активных веществ.

В настоящее время вопросу защиты окружающей среды от различных загрязнений уделяется серьёзное внимание и на исследования в этой области затрачиваются большие средства, что вполне понятно, так как состояние окружающей среды определяет будущее человечества, в том числе здоровье и продолжительность жизни, а также активную деятельность человека.

Одним из источников возможного загрязнения окружающей среды являются химические препараты, используемые для борьбы с различными вредными организмами в медицине, ветеринарии, сельском хозяйстве и промышленности, объединяемые общим названием пестициды [1].

В связи с тем, что пестициды являются биологически активными веществами, к поведению их в окружающей среде предъявляются определенные требования, обеспечивающие наибольшую эффективность их использования и наименьшую вредность для человека, полезность животным и растениям. В связи с этим современные пестициды, прежде чем они будут допущены до практического применения, проходят очень тщательное исследование их поведения в окружающей среде и разрабатываются рекомендации по их безопасному использованию.

Применение пестицидов в сельском хозяйстве дает большой экономический (экологический) эффект и позволяет резко сократить затраты 
общественного труда на единицу вырабатываемой продукции. В настоящее время считается, что без применения пестицидов невозможно получение высоких и устойчивых урожаев практически всех сельскохозяйственных культур. Поскольку большинство продуктов растительного и животного происхождения используется человеком в качестве пищевых продуктов, присутствие в них пестицидов и их метаболитов должно быть строго регламентировано [2].

В современном хозяйстве пестициды находят достаточно широкое применение в следующих основных областях:

- защита растений от различных вредителей, в том числе от членистоногих и грызунов;

- борьба с переносчиками инфекционных заболеваний человека и животных, а также с вредными членистоногими в бытовых условиях, в том числе с комарами, москитами, блохами, вшами, мухами, клещами и др.;

- защита домашних животных от эктопаразитов, таких как подкожный овод, блохи, мухи, вши, слепи и другие;

- защита запасов зерна, продуктов растительного и животного происхождения, неметаллических материалов от повреждения членистоногими и микроорганизмами;

- защита растений от болезней грибкового, бактериального и вирусного происхождения как путем обеззараживания посевного материала, так и лечением больных вегетирующих растений;

- борьба с сорной и нежелательной растительностью;

- защита морских судов от обрастания различными видами организмов, нарушающих нормальную плавучесть судов и уменьшающих скорость хода, что приводит к резкому увеличению расходов топлива;

- борьба с зарастанием каналов и других водных систем;

- регулирование роста растений.

В настоящее время регулирование роста растений используется в самых различных случаях и на большом числе сельскохозяйственных культур, в том числе для дефолиации и десикации растений с целью механизации трудоемких работ по уборке урожая таких культур, как хлопчатник, картофель, бобовые и другие, а также для высушивания растений с корнем.

Регуляторы роста растений используются также для задержки роста молодых побегов, с целью регулирования плодоношения ряда многолетних культур, для борьбы с полеганием злаков, для повышения урожая и получения бессемянных плодов, ускорения укоренения растений при пересадках деревьев и вегетативном размножении черенками, для нарушения состояния покоя и предотвращения прорастания клубнеплодов при длительном хранении, для улучшения цветения цветов и во многих других случаях.

Применение регуляторов роста растений дает прибавку урожая в зависимости от культуры и направления их использования от 10 до 80\%. Особенно эффективно их использование на хлопчатнике, зерновых, некоторых овощных и плодовых культурах. 
На кафедре химии ФерПИ проводятся научно-исследовательские работы по созданию технологии синтеза новых экологически чистых пестицидов и лекарственных препаратов на основе местного сырья для нужд сельского хозяйства, ветеринарии и медицины.

В этом направлении исследований наиболее перспективным является синтез новых экологически чистых биологически активных препаратов на основе гетероциклических и ароматических соединений.

В этом плане бензимидазол и его производные представляют большой интерес как в теоретическом, так и с точки зрения их практического применения. Области использования этих веществ весьма разнообразны. Известны исследования бензимидозолов для синтеза красителей, эмульгаторов, антиоксидантов, лекарственных препаратов, мономеров для получения термостойких полимеров, обладающих рядом уникальных физико-химических и механических характеристик и т.д. [3].
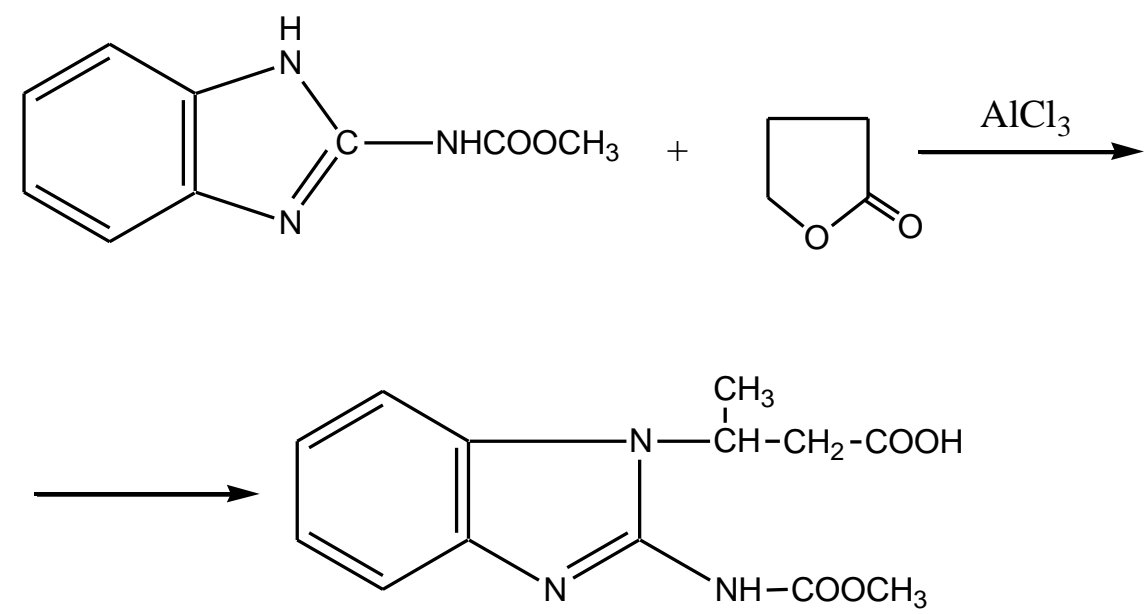

Вследствие структурной близости бензимидозолов к пуринам, витаминам и аминокислотам, они обладают широким спектром биологической активности. Также известны исследования, посвященные синтезу антидепресантов, спазмолитических противоопухолевых препаратов, гипотензивных, противовирусных средств.

Найдены высокоэффективные фунгициды - узген, олгин, деразаль и др. среди бензимидазолкарбаматов. Среди этих классов используются высокоэффективные антигельминтики. В связи с вышеизложенным представляет большой интерес продолжить поиск новых биологически активных соединений среди производных бензимидазолов для нужд медицины, ветеринарии и сельского хозяйства.

В Результате проведенных научно исследовательских работ синтезированы одностадийный синтез карбоксилалкирования 2аминобензимидазола и 2-карбоксиламинобензимидазола. $\gamma$-лактонами и непредельными кислотами по реакции Фриделя-Крафтса. В результате чего получены бензимидазолонилакилкарбоновые кислоты.

По результатам испытаний из синтезированных веществ 2карбометаксиаминобензимидазол и его алкил производные показали высокую 
биологическую активность. Разработана технология получения этого препарата, который может быть рекомендован в качестве снотворного и успокаивающего препарата в медицине и ветеринарии.

Структура синтезированных соединений установлена компьютерными, химическими и физико-химическими методами исследований.

Выявлены новые направления исследований по разработке экологически чистых биологически активных растворимых полимерных пестицидов на основе местного сырья.

\section{Список литературы}

1. Мельников Н.Н., Волков А.И., Короткова О.А. Пестициды и окружающая среда. М. Химия, 1977, с.240.

2. Кадыров Ч.Ш., и др. Машинный поиск химических препаратов с заданными свойствами. Ташкент, ФАН, 1989, с.6-10.

3. Акбарова М.У. и др. Разработка научных основ синтеза биологически активных веществ для медицины, ветеринарии и сельского хозяйства. Отчет ОНИР, гос.регис. 01960004723, Фергана, ФерПИ, 1996. 